\title{
Rapid implementation method of ERP system for large-scale enterprises Hongtao Tang $^{\mathrm{a}}$, Lang Huang ${ }^{\mathrm{b}}$ and $\mathrm{Li} \mathrm{Li}^{\mathrm{c}}$ \\ Wuhan University of Technology, Wuhan 430070, China \\ atanghongtaozc@163.com, bhllwut@163.com, 'Clilwut@163.com
}

Keywords: Large-scale enterprise, ERP, Rapid implementation, Foundry.

\begin{abstract}
More and More Chinese foundry enterprises begin to realize that enterprise resource planning (ERP) is very critical to their business development. This paper analyzed the characteristic of Chinese large foundry enterprises' ERP implementation and put forward quick implementation method of flexible ERP system for large-scale foundry enterprises. The method had been successfully applied to a large-scale foundry enterprise, and the results were evaluated qualitatively and quantitatively. The results illustrate that this method could respond quickly to enterprise needs in the ERP implementation, achieve successful ERP implementation in a short time. It is a useful reference to the ERP implementation in foundry enterprises.
\end{abstract}

\section{Introduction}

In recent years, foundry enterprises develop from small and medium-scale to large-scale, with management modes developing from family management to group control. The number of Chinese large-scale foundry enterprises will increase in the next period of time. System integration, business integration and group control have become the main task of the large-scale manufacturing enterprises informatization construction. As a good combination of advanced management ideas and information technology, enterprise resource planning (ERP) has been a powerful management tool to reform traditional manufacturing enterprises [1-2]. Experts and scholars at home and abroad put forward a lot of methodologies and carried out a large number of empirical studies [3-4]. However, despite the attributes and major advantages provided by ERP systems, the implementation of such systems is not always effective [5]. Low success ratio of ERP implementation is a major problem which puzzles the academic and business circles.

Above all, we can summarize the following two points: (1) ERP becomes an inevitable choice for large-scale foundry enterprises to achieve development. Considering the rapidly changing market environment, ERP requires not only successful implementation but also quick implementation. (2) Business process reengineering and optimization, as the main content of ERP implementation, is the key to successful implementation. The ERP applications of foundry enterprises are not optimistic, obviously far behind other industries, especially in the large-scale foundry enterprises. On the one hand, the multiple and complicated foundry processes cannot be easily brought into the integrated management. On the other hand, the general ERP software supplied by the vendors based on the general theories cannot satisfy the specific production mode of foundry enterprises [6-7]. This paper put forward the rapid implementation method for large-scale foundry enterprises based on the technology, evaluated the effectiveness of this method qualitatively and quantitatively with a case study which introduced a successful application in a Chinese large-scale foundry enterprise.

\section{Methods}

\subsection{Rapid implementation method}

The ERP rapid implementation method for large-scale foundry enterprises is illustrated in Fig 1. The whole implementation process is divided into three periods, in which the implementation team works on the spot for 30 working days in total. The time for enterprises' ERP system to reach a successful and stable-application goal is about 90 working days. The contents of the three periods are introduced as follows. 
(1) Basic training. The main task of this period is teaching members of each department basic operations of ERP system, for example, entering, deleting, and filtrating, etc. ERP implementers introduce every basic function of the system to the main operators, let them practice training contents and evaluate their operation situation in each department of enterprise for a week. The overall situation will be summarized at the later stage of this period.

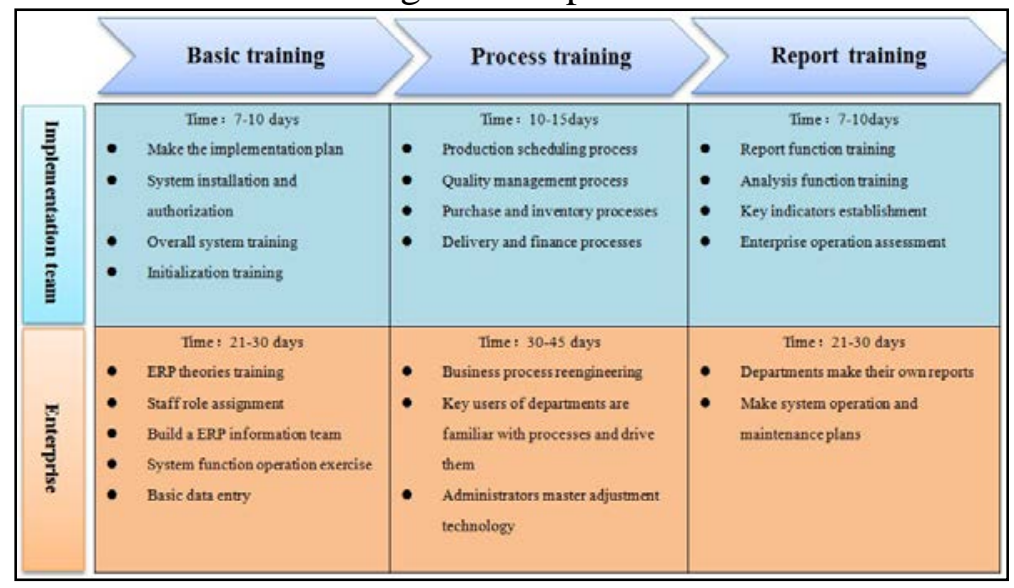

Fig. 1 Rapid implementation method

(2) Process training. The main focus of this period is production and the ambition is driving the whole enterprise processes through the smooth execution of production process, which reflects the core production-centered value of ERP. In this period, as the main participants, planners promote other processes of ERP: order, technique, quality, logistics and so on.

(3) Report training. After the basic training and process training, the information processes of enterprise have been established and stably operated. Each department has worked cooperatively under the guidance of the ERP system. The ambition of this period is cultivating the capacity of post-mortem analysis in the whole enterprise. In addition, as the important part of measuring production value, the financial information-based procedure will be set up in this period.

\subsection{Evaluation methodology}

In order to distinguish the ERP rapid implementation method for large-scale foundry enterprises based on module flexibility with other implementation methods, and answer the question how to reflect this method's rapid feature, this paper attempted to evaluate this method qualitatively and quantitatively. It judged qualitatively whether the method could promote the information flow of enterprise, then drastically reduced the labor and time cost in the process, and evaluated quantitatively the ERP system application degree of enterprise and the ability to meet the requirement of internal process change.

Qualitative evaluation and analysis include:

(1) We build user analysis reports in the system at the beginning of implementation which faithfully records the users' operational information, for example, the login number, online time and amount of data processing. Based on these reports, we assess the job performance of users (performed by $\star$ ), which is shown in Fig 2 .

Quantitative analysis indicators include:

(1) Form competence degree:

$\mathrm{Fa}=\mathrm{SUM}$ (if (Ui is null, 0,1$)$ )/ (Li*Ri).

Ui equals 1 when the contents of table cells are not null, otherwise 0 , which is added to get the numbers of relational database form entry cells. $\mathrm{Li}$ is the total number of rows, and $\mathrm{Ri}$ is the total number of columns. We get the total number of table cells when the Li multiplies Ri. Fa is applied to assess the job completion of users. The bigger value (the maximum is 1) means the better jog completion. In the data initialization stage, we use the mean value of this indicator to measure the data operation ability of enterprise, which is qualified when the value is greater than or equal to $80 \%$, good when $85 \%$, and excellent when $95 \%$.

(2) Average time of meeting module demand:

$\mathrm{Ta}=\mathrm{AVG}(\mathrm{Ti})=\mathrm{SUM}(\mathrm{Ti}) / \mathrm{N}$. 
$\mathrm{N}$ is the sum of reasonable demand points based on module flexibility technology, and $\mathrm{Ti}$ is the cost time of meeting any demand. After 90 working days of rapid implementation, the administrators of ERP system from enterprise can use module flexibility technology to satisfy the requirement of business process changes. Ta is the effective indicator of evaluating this ability. The smaller value means the greater reaction capability of enterprise. $1 \mathrm{~h}$ is the threshold of this indicator, and $\mathrm{Ta}<24 \mathrm{~h}$ means the remarkable ERP implementation effect of enterprise.

\begin{tabular}{|c|c|c|c|c|c|c|c|}
\hline \multicolumn{7}{|c|}{ (9) Data Analysis-User Analysis } & 미 \\
\hline Data tools & 000 & 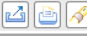 & 世 圆 郹 & & $\square 1$ & $\cdot$ & Exit \\
\hline \multirow{19}{*}{ 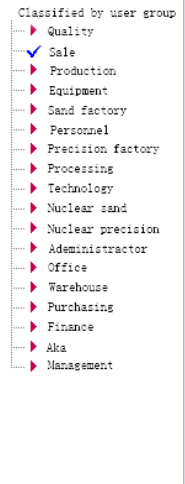 } & \begin{tabular}{l|l} 
usp & User
\end{tabular} & User Grovp & Average Day & Vitality & Star & & \\
\hline & Wang HY & Sale & 15 & 2 & $\star \star$ & & \\
\hline & Zhang $\mathrm{I}$ & Sale & 16 & 2 & $\star \star$ & & \\
\hline & LIU HY & Sale & 18 & 3 & $\star \star \star$ & & \\
\hline & Zhang WD & Sals & 22 & 3 & $\star \star \star \star$ & & \\
\hline & Wang $\mathrm{C}$ & Sale & 21 & 3 & $\star \star \star \star$ & & \\
\hline & $\operatorname{Goz} z$ & Sale & 21 & 3 & $\star \star \star$ & & \\
\hline & Zhu XW & Sals & 18 & 3 & $\star \star \star$ & & \\
\hline & Yao Q & Sale & 19 & 3 & $\star \star \star$ & & \\
\hline & $\mathrm{xU} \mathrm{Kz}$ & Sale & 19 & 3 & $\star \star \star$ & & \\
\hline & $W_{v} N Y$ & Sale & 21 & 3 & $\star \star \star$ & & \\
\hline & Zhang S & Sale & 22 & 3 & $\star \star \star$ & & \\
\hline & $\mathrm{Hu} \mathrm{XF}$ & Sale & 23 & 3 & $\star \star \star$ & & \\
\hline & Zhang GM & Sale & 24 & 4 & $\star \star \star \star \star \star$ & & \\
\hline & Wang CL & Sals & 25 & 4 & 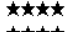 & & \\
\hline & Zheng DF & Sale & 24 & 4 & 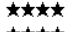 & & \\
\hline & Liang GB & Sale & 25 & 4 & $\star \star \star \star \star$ & & \\
\hline & Chen HL & Sale & 25 & 4 & $\star \star \star \star \star$ & & \\
\hline & $\mathrm{M} 2 \mathrm{M}$ & Sale & 24 & 4 & $\star \star \star \star \star$ & & \\
\hline
\end{tabular}

Fig. 2 Job performance assessment

\section{Case Studies}

\subsection{Company background}

A Company, which was found in 1986, was a professional foundry enterprise of valve castings. Along with the rapid development of enterprise, the dramatic increase of personnel, product variety and production, the customer requirement diversification and the higher and higher quality requirement, company management becomes more complex. The original systems such as production management system, workflow system, OA system could not catch up with the changes of company management. Problems such as lack of precise production and quality control, systems' lack of intelligent drive, mutual restriction control features, systems incompatibility and data inconsistency make it hard for management to respond to market demands quickly. In order to improve the enterprise overall management level, the professional foundry ERP system was introduced in August, 2013.

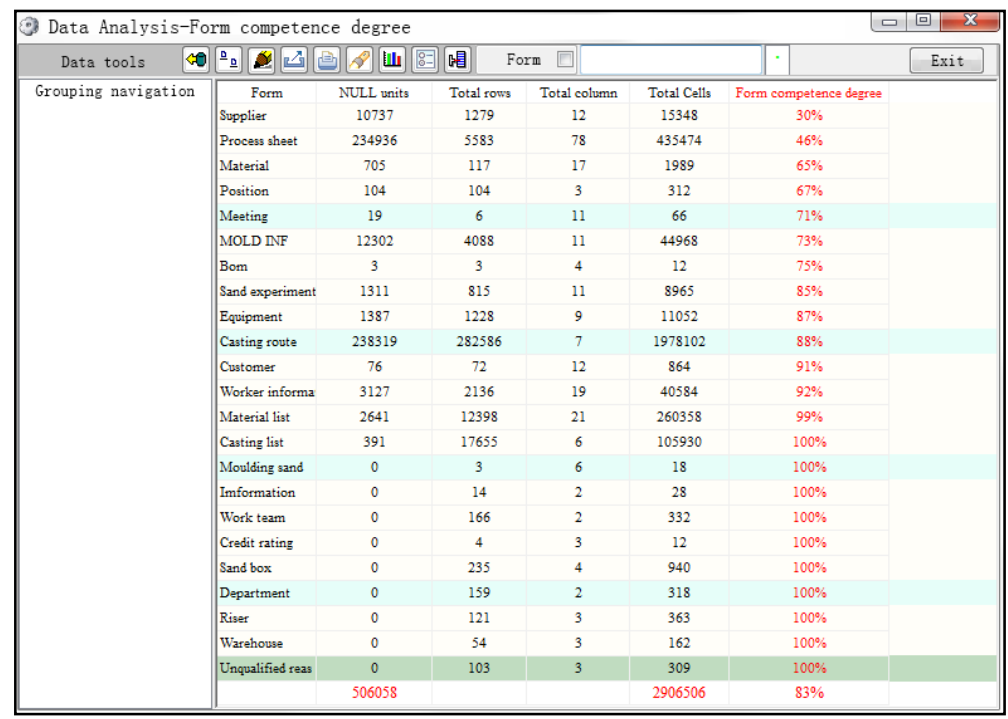

Fig. 3 Form competence degree of A Company 


\subsection{Results}

(1) It cost the implementation team 50 days and the enterprise 90 days to implement ERP successfully. The team consisted of 4 casting informatization implementation consultants and a flexible ERP system.

(2) According to the data analysis which is shown in Fig 3, the overall form competence degree of A Company by the end of January 2014 is:

$\mathrm{Fa}=\mathrm{SUM}$ (if (Ui is null, 0, 1)) $/(\mathrm{Li} * \mathrm{Ri})=2400448 / 2906506=83 \%$

(4) The consuming time of every demand point base on module flexibility technology is shown in Fig 4 . The average time of meeting module demand is:

$\mathrm{Ta}=\mathrm{AVG}(\mathrm{Ti})=\mathrm{SUM}(\mathrm{Ti}) / \mathrm{N}=4.3 / 11=0.39 \mathrm{~h}$

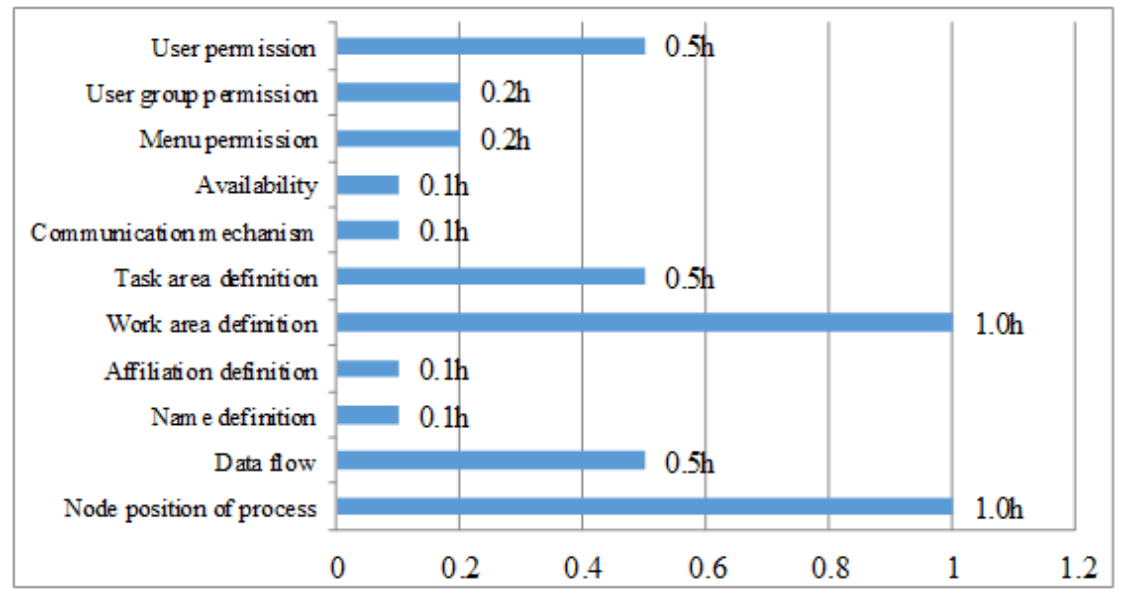

Fig. 4 consuming time of every demand point base on module flexibility technology

\section{Conclusions}

This paper put forward rapid implementation method of flexible ERP system for large-scale foundry enterprises. Through the actual case of A Company, the method was evaluated qualitatively and quantitatively. It also provides profits and references of implementing ERP for large-scale foundry enterprises. The significance of implementation results leads us to three conclusions.

(1) Compared with the traditional ERP implementation cycle of more than one year, the rapid implementation method based on module flexibility technology, which was a part of instant flexibility approach, could shorten the whole ERP implementation cycle to 90 days for the enterprises.

(2) The module flexibility technology could meet all module requirements of a large-scale enterprise in a short time of less than 24 hours.

(3) The flexibility technology is the foundation for rapid and successful ERP implementation.

\section{Acknowledgements}

This research was financially supported by Project supported by the National Nature Science Fund Project, China (NO.71171154), the Fundamental Research Funds for the Central Universities(2013-YB-021, 2014-IV-016).

\section{References}

[1] J.X.Zhou, F.Liu and L.L Chen: Foundry, Vol. 57 (2008) No.9, p.885.

[2] J.X.Zhou, X.Y.Ji and D.M.Liao: China Foundry, Vol. 10 (2013) No.1, p.7.

[3] Q.F.Min: Empirical research on critical success factors of Chinese enterprises' ERP system implementation (MS., Dalian University of Technology, China 2005), p.20.

[4] C.L.Liu and J.S.Peng: Science Research Management, Vol. 27 (2006) No.2, p.128.

[5] M.Mahdavian and F.Mostajeran: Int J Adv Manuf Technol, Vol. 69 (2013) No.9-12, p.1981. 
[6] F. Liu, J.X.Zhou and L.L Chen: China Foundry Machinery \& Technology, Vol. 43 (2008) No.6, p.57.

[7] J.Song, J.X.Zhou and L.L.Chen: Foundry Technology, Vol. 31(2010) No.6, p.788.

[8] 